\title{
The Butaque. From the colonial codices to the archetype of 20th century Mexican design
}

\author{
DOI: $10.46932 / \mathrm{sfjdv} 3 \mathrm{n} 1-065$
}

Received in: Jan 30st, 2021

Accepted in: Feb 1th, 2022

Dra. Mercedes Josefina Hernández Padilla

Doctor in Architecture, Design and Urbanism,

Art, Architecture and Design University Centre, of the University of Guadalajara, México. Calzada Independencia Norte 5075, Guadalajara, Jalisco, México, Zip Code 44250.

E-mail: mercedes.hernandez@academicos.udg.mx

\begin{abstract}
Following the Mexican Revolution war, a program began for the dissemination of certain symbols of national identity-to redefine the Mexicanity. The search was expressed in fine and decorative arts, including furniture. In this context, the "Butaque" chair reappeared.

Architects such as Luis Barragán, William Spratling, Clara Porset, and Manuel Parra, among others, proposed their own interpretations of this traditional rural seat, inserting it into a new socio-cultural context, making it a representative piece of the 20th century Mexican furniture. Despite its significance, there have not been many studies or publications on the piece, and mystery surrounds it's origin.

The purpose of this text is to present a hypothesis about the origin of the "butaque" in the colonial codices, and to revaluate it as a mestizo seat, that is a combination of European manufacturing techniques and technologies with materials, labor and ability of the Mexican indigenous, making it a worthy representation of Mexican cultural identity.
\end{abstract}

Keywords: Mexican armchair, Codex, Identity, Mexicanity, Mexican Design.

\section{INTRODUCTION}

At the end of the War of Mexican Revolution, with the creation of the Public Education Ministry in 1921, leaded by José Vasconcelos, a program began and its main objective was the dissemination of different national identity symbols, initially seeking in the miscegenation and shortly after in the indigenous cultures, the diverse social unifying elements with the purpose of defining the so-called Mexicanity (Calderón Pichardo, 2018); This search was not limited only to the fine arts, of which the Mexican Mural Movement, nationalist architecture, music and cinema can be named, but also the decorative arts in general, and furniture design in particular, that from the exhibition and publication named "The popular arts of Mexico" (Murillo, 1985), that dignified at the museum level the handmade crafts for daily use (Oettinger, 2009), a fact that contributed to the promotion and consolidation of a cultural identity, based on Vasconcelos aesthetic philosophy.

Since then and during the rest of the 20th century, Mexican design and furniture, as well as 
Mexican cultural identity, were characterized by its roots with the Mesoamerican and colonial past, tied to applied arts and so-called popular art, revaluating old forms, uses and functions of various pieces of furniture, hitherto widely used among the most modest social groups.

It's in this context that the Butaque, also known as the Campeche chair, reappears; an artisan manufacture rest chair, used in the tropical regions of the Gulf of Mexico, and with some regional variants, in various rural areas of Mexico; these seats were made by the colonial farms peasants and laborers for their own use, and they also made in better quality woods and finishes for the lords,

From the late 1920s until 1970's, architects and designers such as Luis Barragán, William Spratling, Clara Porset, Michael van Beuren, Manuel Parra and Alejandro Rangel Hidalgo, proposed their own Butaque interpretations, inserting them in a new sociocultural context, combining tradition, modernity and cultural identity in the twentieth-century Mexican furniture, crossing borders through the Mexico embassies furnishing around the world, and until very recently, in Los Pinos furniture, the former Mexican Government Official residence.

Despite its significance, studies and publications about the Butaque have been limited, and neither about its origin, unlike other European or American origin seats; but its manufacture, use, typology, commercialization and even its exportation has been possible to trace until the late seventeenth century, in various regions of Mexico, the southern United States and in the Caribbean Islands.

The objective of this work is to present a hypothesis about the origin of the Butaque in the colonial codices, and to revalue it as a mestizo seat, a combination of European manufacturing techniques and technologies with local materials, Mexican indigenous labor and ingenuity product, and therefore, a worthy representative of the Mexican cultural identity.

For this research work, various publications and papers referring to the Mexican art history, Mexican furniture history, as well as magazine articles and other publications of a scientific and historical nature whose central issue was furniture and / or the decorative arts in Mexico were used. The preHispanic and colonial codex kept at The National Institute of Anthropology and History Library, facsimile and printed reproduced collection; photographs, data and cataloging files, which are found in the National Institute of Anthropology and History digital repository, as well the pieces kept at some museums, like the National Anthropology Museum and Modern Art Museum, both in Mexico City, "El Palacio" Museum in Campeche, Great Museum of the Mayan World in Mérida, Rangel Hidalgo University Museum in Nogueras, Colima; and also the Philadelphia Museum and the Metropolitan Museum in New York City, in the United States of America, on line catalog.

The observation and comparative analysis of the data contained in the series of documents obtained, books and specialized publications of previous research, was the method used in this work, as 
part of a more extensive research about the Mexican furniture history.

\section{THE BUTAQUE}

The Butaque takes its name from the Spanish word "Butaca" (Seat), after being tropicalized word from French or Creole Louisiana's language as “Boutaque”, it is also known as Campeche Chair, the city and port of Campeche, that it was exported from to different latitudes, even to peninsular Spain. It is an artisanal manufacturing rest seat elaborated in pinewood the most rustic version, or in precious woods from each region the most luxuries ones.

Two boxed assembled asymmetrical stringers constitute its lateral structure, forming an " $\mathrm{X}$ " shape, which the longest element conforms the backrest; at the bottom, some simple wooden sticks, serve as braces. The continuity of the seat and backrest, as well as the two crossed string, and the "S" shape at the front view are the features that distinguish it from other types of seats, added to the achieved inclination, make this a extremely comfortable furniture, intended for rest.

The oldest example known, is the piece at the Philadelphia Museum collection (Philadelphia Museum of Art, 2018), manufactured with mahogany with chiseled leather upholstery and fixed with bronze nails, and according to their data, it was manufactured between 1730-1770, by the exuberantly scallop shell carved in its arched crest, that was frequently used as a decorative motif along the Mexican baroque period.

The butaque was also a seat widely used in the Louisiana plantations houses (Gontar, 2003), in the United States of America, market that came first, through the trade that was had with the new Spain, specifically between the port of Campeche and the city of New Orleans, which up to 1800 was Spanish territory, but with a great French-speaking population ${ }^{1}$; expanding its use to the southern states of the country, and due to the demand for the lords of the plantations, some specimens were reproduced with the workforce of the slaves. The former president of the newly United States of North America, Thomas Jefferson (1801-1809), had several examples in his Monticello residence, in the state of Virginia, and in his letters he denoted the emotional attachment he had towards a particular armchair, writing about its comfort. At present time, the whereabouts of this particular chair is unknown, but in the James Madison Museum in Orange, Virginia, examples are exhibited from both Mexican and American origin, distinguishing on the carving of the crest and the chiseled leather of the upholstery presenting in Mexican pieces.

\footnotetext{
${ }^{1}$ The French Louisiana was declared French territory in the late 17th century; After the 7 Years' War, by the Treaty of Paris it was ceded to Spain in 1763; In 1800 France acquired it again, by the Treaty of San Ildefonso, and finally, sold it to the United States of America in 1803. Trillo, Manuel; When Spain dominated the gigantic Texas and Louisiana with a handful of men; on ABC, published on June 17, 2018, Seville, Spain. Retrieved August 6, 2019.
} 
In Mexico, El Palacio Cultural Center in the city of Campeche, in the room dedicated to commerce, there are three butaque copies exhibited, one with armrest in scroll shape and two without armrest, the three of them have leather nailed to the frame upholstery, and they were part of the manufactures that were commercialized, and even exported from this port, to Veracruz and from there to destinations such as Havana, Cádiz, Málaga (Rivas Pérez, 2017) and New Orleans, and it was reported and manifest of the cargo taken on board the Jenny at Campeche, dated April 1808, in which four Butaques were declared (Gontar, 2003).

Figure 1. Butaques from 17th to 19th centuries. Sup. Left to right: A. Armchair, 1730-1770, Philadelphia Museum, Pennsylvania, digital catalog, inv. 2012-178-1, https://philamuseum.org/collections/permanent/313148.html, drawing by: AMTR. B. Campeche Chair, ca. 1820, James Madison Museum, Orange, Virginia, digital catalog, https://www.thejamesmadisonmuseum.net/exhibits?lightbox=dataItem-ifla9rtn, drawing by: AJRT; c. 19 ${ }^{\text {th }}$ Century Butaque, Great Museum of the Mayan World of Mérida, Yucatán, photograph: MHP, drawing by AMTR; d. Campeche Chair, S. XVIII, Museum of Colonial Art, Havana, sd. Cuba, MHP photography, drawing by: JRRT; Bottom: e. deerskin upholster Butaque, S. XIX, origin of Yucatán, recovered from: https://donshoemaker.com/what-is-the-difference-between-a-mexican-campechechair-and-a-butaque-part -2 / \# jp-carousel-5797, JRRT drawing; F. Tehuantepec, Oax Popular region seat, 20th century, Ethnography $18^{\text {th }}$ Room, National Museum of Anthropology, photograph: MHP, drawing by JRRT; g. 19 ${ }^{\text {th }}$ Century Butaque, "El Palacio" Cultural Center, Campeche, Campeche, s /d, photograph: MHP, drawing JAIJ.
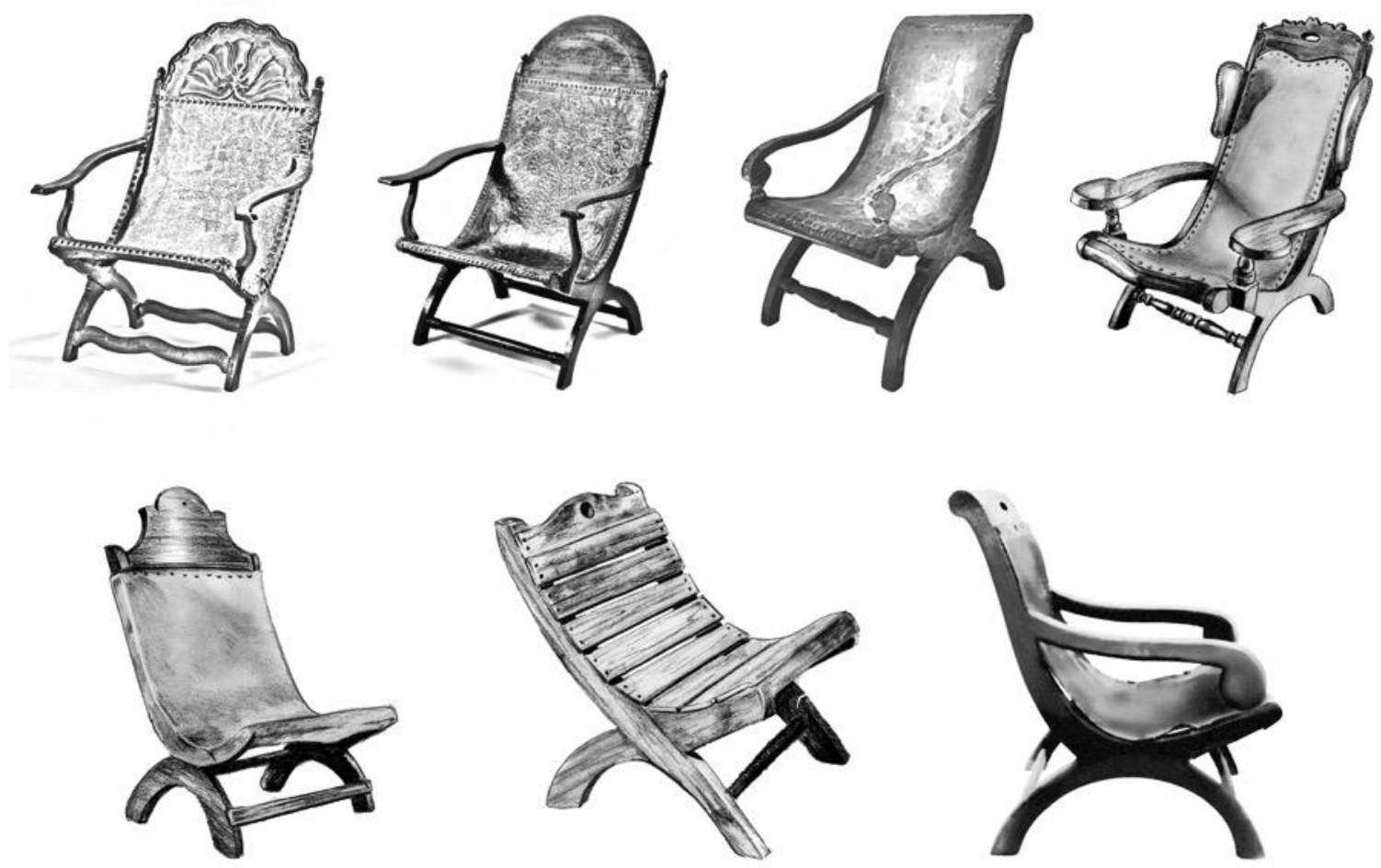

At the Great Museum of the Mayan World, a simple butaque without armrests is on display as part of the goods that were marketed and exported from the Yucatan captaincy, as well as a butaque made in finer wood, with turning armrests and crossbars, upholstered with leather nailed to the frame. (Figure 1)

About the origin of the butaque or Campeche Chair, there is a few information; We assume that this kind of chair possibly appeared between the end of the 16th and the beginning of the 17th century, as a result of the cultural exchange between Europeans and Americans, because the American inhabitants 
did not have the carpentry and cabinetmaking skills of and neither the tools, then these were transplanted from Europe and disseminated throughout the continent after the conquest period.

There are few Mexican furniture specialists that have mentioned the butaque; per example, Ana Elena Mallet (2017), in her book Mexican Chair, that it is an exhaustive inventory of the twentieth century Mexican seating, includes a section dedicated to the butaque in which Jorge Rivas Pérez attributes the origin of the Campeche Chair to a ceremonial seat called "Duho" that were used by the Tahinian people in the Caribbean Isles, Rivas explains that by the similarity in the curved profile that form the seat and high backrest of this kind of seat, from which the seat called "Ture" is derived (Rivas P., 2007), and these were a result of the adaptation of an autochthonous seat, made with the sixteenth century European technology; Likewise, he affirms that it was taken from Venezuela to New Spain (Rivas Pérez, 2017). While there are similarities, the stringers are completely straight, while in the butaque the stringers are curvilineous and form two half-circles, so they are more comfortable, beyond the harmony and balance of the whole piece.

Cybèle Trione Gontar (Gontar, 2003), in her analysis of the Campeche chair, attributes its origin to an evolution of the Roman curule seat, which also presents an " $\mathrm{X}$ " -shaped frontal view, as well the hip-joint arm chair, and the Italian folding chair, also known as Dantesca and Savoranola or Florentine chair, which they allow folding, since the crossing of both supports forms an axis that allows this movement, and both the seat and the back are made of leather or textile, which facilitates its portability.

Teresa Castello de Yturbide (Regional Furniture, 1969), describes the regional variants of the armchair in Jalisco, Campeche, Yucatán, Oaxaca, and she classifies them as popular or folk furniture.

Abelardo Carrillo y Gariel (1957), makes a very brief comment, attributes its Spanish origin, due to the similarity with the jamuga or hip-joint chair, since in some colonial codex, like the plates of the Tlaxcala Codex, several Spanish characters are represented, on seats with the distinctive " $\mathrm{X}$ " shape on the side and not on the front, as in the hip chair.

Looking for the primary sources that Carrillo mentions, some question arose, like which is that seat present in the colonial codex? Was it the same hip-joint chair or another kind of seat? If it is derived from the hip-joint chair, how was that transformation like? Finally, if this seat is an European furniture appropriation of shapes and uses? Or is it an original seat from the Mexican territory? If so, then the armchair would have sufficient attributes to represent 20th century Mexican furniture. To respond to these questions, it was resorted to those publications that addresses with the Mexican furniture origin, more precisely European furniture that was brought to America, and the way that the society adopted them throughout the 16th century. 


\section{THE EUROPEAN SEAT ARRIVAL TO MEXICO}

There were two kinds of seats that were brought from Spain or Europe to Mexico, and they had been documented in the 16th century chronicles, the French or imperial chair and the hip-joint chair. Both types of seating are mentioned in the Carpenters and Carvers Ordinances and also in various houses and palaces inventories.

Those Ordinances were issued by the City Council of Mexico and approved by the viceroys on August 30, 1568, there were confirmed by the Royal Governing Court on October 26 of the same year. In these Ordinances, in addition to guaranteeing the quality of what was bought, it mentions that the carver to be examined must knew how to make a desk with its covers and bases, moldings, architrave and cornices, a portable turned bed, a six-piece table, a French chair, and a inlaid hip-joint chair as a requirement to have a store. (Garabana, 1969)

Regarding the seats, the French chair is distinguished by a straight and rigid structure, with a high back formed by the typical Renaissance arches with turned bars or simply by brocade velvet attached to the bars, with a seat in studded calfskin or the same thick fabric, which served as inspiration for later styles; this type of chair is also known as "friar chair", since its use was quite frequent in catholic monks missions and monasteries, although later they were enriched by adding carvings, armrests, and upholstered with luxurious textiles; but the lines and right angles structure, in the front and side views is its distinctive appearance. (Figure 2)

On the other hand, the hip-joint chair, also known as Florentine, Dantesque or Jamuga, is a double scissor seat that allows it to be folded. It is made up of four curved uprights in "S" shape, and they are articulated in pairs whit their intersection point, cut out in a circular shape decorated with geometric motifs inlaid work, and allows the half turn to allow folding; both were joined at the base by two brackets, two crossbars on which the seat was affirmed and two curved arms that are raised to receive the backrest. The seat and back were made of leather, some of them simple or embossed, also with embroidered velvet and other with gold stripes, which in addition to their own function of supporting the body, prevented the chair from opening more than convenient. 
Figure 2 Examples of types of seats of European origin used during the 16th century in Mexico: left. French chair with wooden arms and open velvet for the seat and back, fixed by ovoidal nails, back with embroidery, frontal frame, of Spanish manufacture; Dated between 1501-1600, MNAD, Madrid, digital catalog, inv: CE00529, http://ceres.mcu.es/pages/Main. Right Hip-joint chair or jamuga, carved wood and stitched leather seat, 16th century, Cuauhnáhuac Regional Museum, Cuernavaca Mor., Photograph: MHP. Drawings by: JRR.
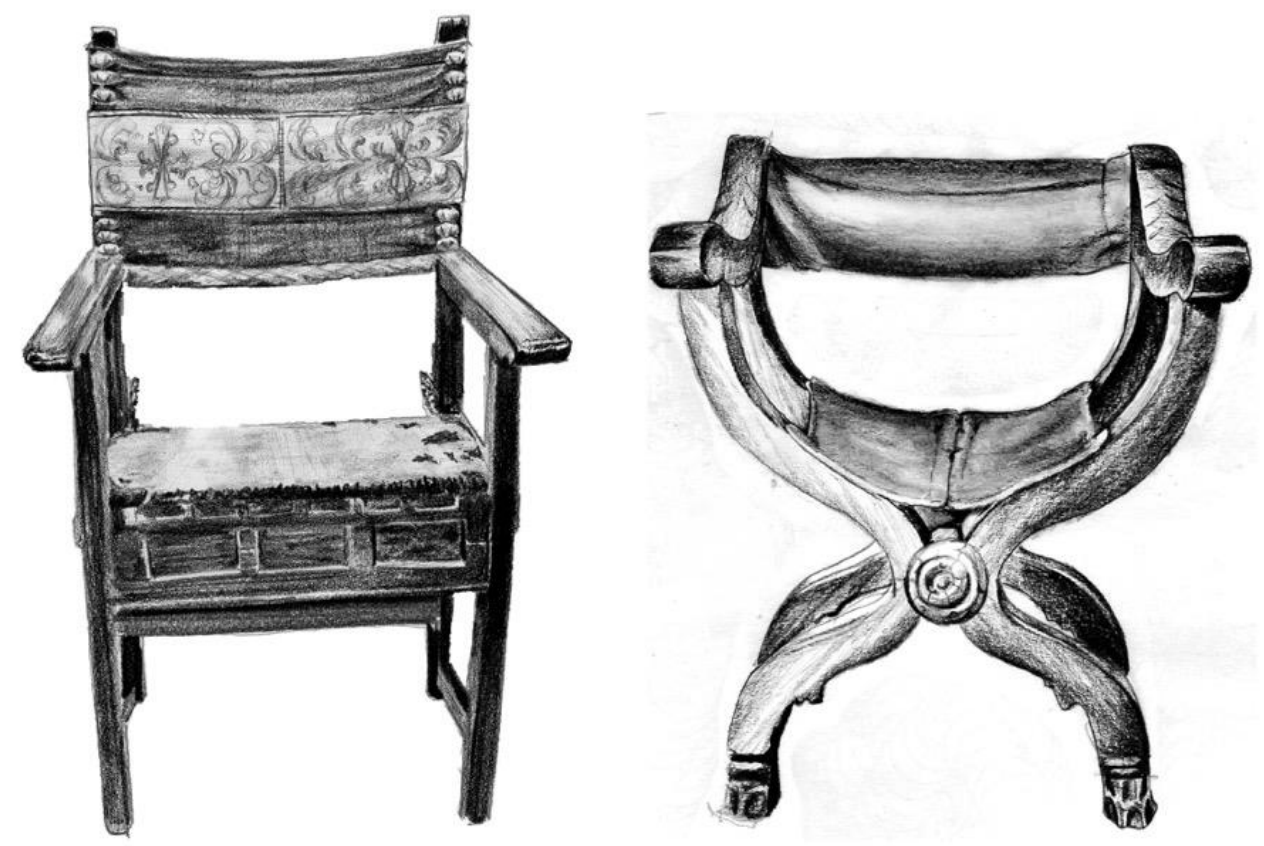

The inlayed hip-joint chair is widely documented by the conquest chroniclers, such as Bernal Díaz del Castillo, in the True History of the Conquest of New Spain (Díaz del Castillo, Historia verdadera de la Conquista de la Nueva España, 1795), he described the gifts that Cortés sent to Montezuma with Tendile:

"And then Cortés sent for a hip chair, with heavily carved paint..."

And then he wrote:

"... then send that chair in which Mr. Montezuma must sits, so that when Cortés goes to see and speak to him"

Since that historic meeting between Hernán Cortés and Montezuma, the hip-joint chair was related to a seat of power, reserved for the senior character ${ }^{2}$. This scene was documented in the $\mathrm{K}$ frame on the second line of the Tlaxcala linen, drawn up in the 16th century (see figure 3); Hernán Cortés himself is always represented seated on this kind of chair, as well as the Spaniards, monks and landowners.

\footnotetext{
${ }^{2}$ In Mesoamerican cultures many types of seats were used, but only the Huey Tlatoani or emperor used exclusively the Icpalli, a taller and more elaborate seat than the others, so since before the arrival of Cortés, the use of high seats it was reserved for those who possessed the highest political and social hierarchy.
} 
Figure $3 \mathrm{~K}$ marked Box from the Tlaxcala Codex, 16 $6^{\text {th }}$ century, 1773 copy. Códices de México, INAH., Retrieved from: https://www.codices.inah.gob.mx/movil/contente.php?id=50: drawing by JAIJ.

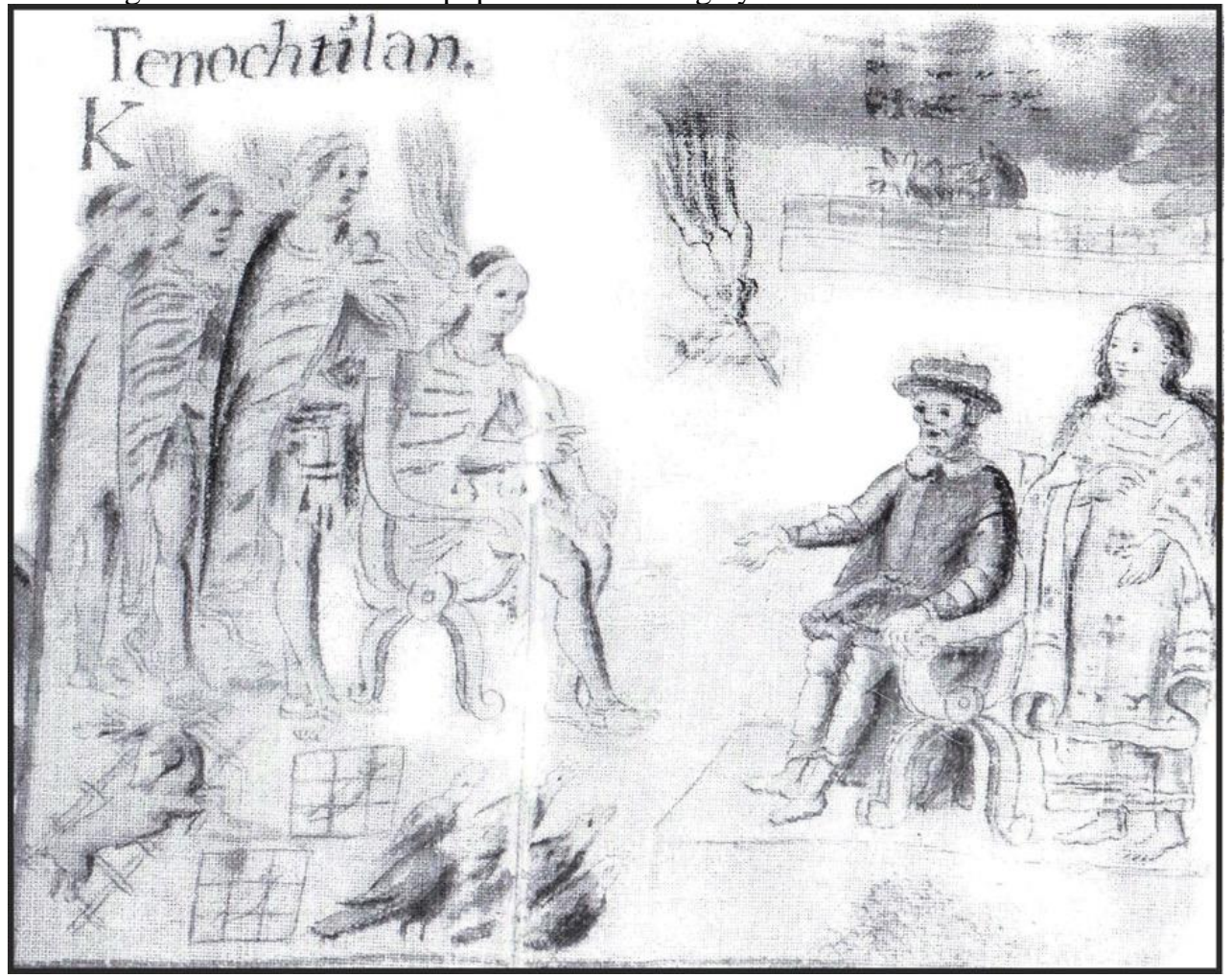

\section{THE MEXICAN CODEX AND THE PICTOGRAPHIC LANGUAGE}

The codex (from the Latin Codex, which means "manuscript book") (Galarza, 1996) are the pictorial or image documents that were made by the indigenous cultures of Mexico ${ }^{3}$ and Central America, and in them they recorded their knowledge and provide information about their history, before the arrival of the Spaniards and even after the conquest, the production continued taking place until the eighteenth century. At present time they are considered as first-hand historical sources, since, beyond being one of their artistic manifestations, they left testimony of indigenous vision, embodied in its writing system, and as such, the information provided by these documents is valuable, as the chronicles and other writings of the Spanish conquerors and friars of the sixteenth century.

\footnotetext{
${ }^{3}$ Those in charge of preparing these manuscripts were called Tlacuilos, which means "the one who wrote by painting", and they were men and women who had deep knowledge of their language and the knowledge of their time, since they attended the Calmecac, so they should also have great drawing and painting aptitudes; They were considered as the knowledge perpetuators and they were assigned to various institutions in which they have been specialized in religion, economics or civil matters; Also by themselves were the readers of those documents, since the tlacuilo understood the pictograms meaning and could interpreted the information according to what was required.

During the conquest period, many of these documents were systematically destroyed, either in the taking and looting of the amoxcalli (book houses, the equivalent of current libraries), as well as in the so-called "faith acts" organized by the friars since they considered these books as "works of the devil." A few codices could be protected from this destruction, since the same friars, chroniclers and historians, such as Sahagún, Motolinia and Torquemada among others, valued the information contained in these strips, and resorted to the same tlacuilos to let them read the content to them and also, help them write their own chronicles. Others were sent as gifts to the King of Spain, so in total, less than 20 codices are preserved, and only two of them are kept in Mexico.
} 
They used pictographic language for elaborate them, which is characterized by stylized and detailed drawings, to represent each and every ideograms, characters and scenes, objects, animals; Most of them were represented in side face, thus the physiological characteristics of the face, the clothing, the body ornaments could be embodied more accurate. In some cases, the torso could be represented from the front, but the legs and feet were represented from the side and a little separated between them. Most of the pre-Hispanic codex have these features, although each region had their own style and aesthetic code, hence they were classified according to the region or ethnicity that produced them, such as Mixtec, Mexican and Mayan codex. (Figure 4)

Figure 4. Pre-Hispanic codices: Left, Nutall Codex, Plate 80, drawing: Lacambalam, recovered from: https://commons.wikimedia.org/wiki/File: Lámina_del_Códice_Nuttall.jpg; right: Codex Borgia, plate 73, taken from Díaz Gisele, and Rodgers Alan, The Codex Borgia, p. 5.
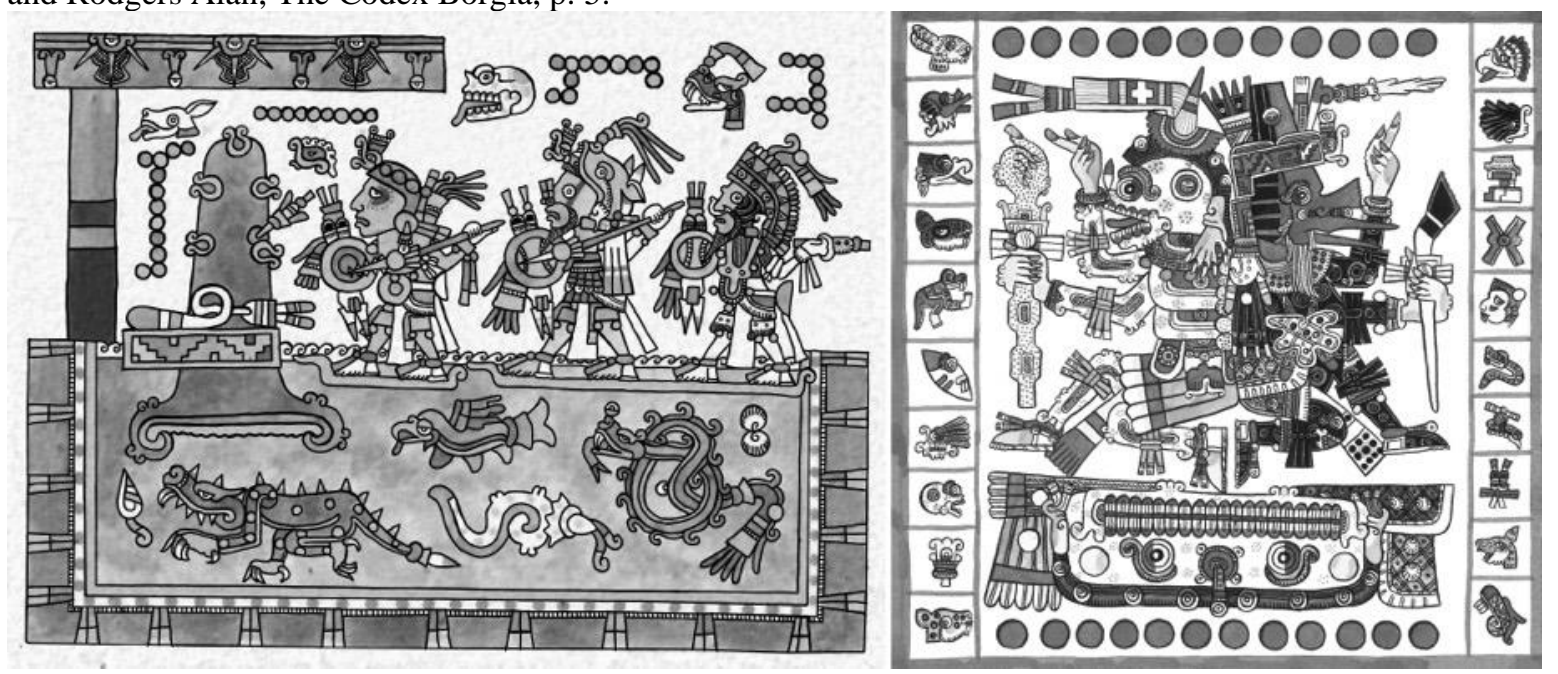

It was in schools founded by the friars, such as the School of Arts and Crafts that Pedro de Gante a Saint Franciscan friar, founded next to the San Francisco Convent in Mexico City, (Toussaint, 1990) which the Renaissance techniques of painting, such as the axonometric perspective, were taught to the indigenous artists, as well as the realistic figurative composition, opposing to the abstract stylization of indigenous pictographic techniques. These new ways of representing reality can be reflected in the frescoes inside the Franciscan and Augustinian churches and monasteries scattered around the center of the country.

Thus, all the important events should be registered in the indigenous language and the manner to give legal value, so the so-called colonial codes appeared. In these documents, the conservation of the pictographic technique was possible; Pedro de Gante himself resorted to that technique to create the catechism and some catholic prayers to make easier its memorization among the indigenous people; Another important Franciscan friar Bernardino de Sahagún with the help of a tlacuilo, also used this pictographic language in the preparation of the Florentine Codex (1540-1585), which the friar wrote 
himself the translation in Spanish, which was subsequently published as the "General History of The Things of the New Spain ".

The Tlaxcala Codex is another colonial codex example, it was made between the years 1535 and 1550 , in which the region political structure was documented, as well as some important events in which Tlaxcaltecas accompanied the conquerors, and also the privileges that some indigenous caciques received by that alliance. These are considered as mixed codex, since although they retain the tlacuilo style and pictographic technique, some European Convention drawing elements were incorporated, such as the almost realistic way to representing the characters and objects, and in some of them there are phrases in Spanish language combined with pictograms. (Escalante Gonzalbo, 2010)

In these colonial codices, among other objects, it is possible to observe the Spanish furniture used, especially by friars and conquerors, such as benches, desks and hip-joint chairs, as in the Cuetlaxcohuapan Codex. In the sixteenth century codices in which Spanish characters are represented, they appear seated on the same kind of seat, like in the Tlatelolco Codex, prepared in 1562, which covers a historical sequence from 1542 to 1560 (Valle, 2008), on its first sheet appear represented an indigenous character, maybe Diego de Mendoza Imauhyantzin, who was the Tlatelolco cacique, seated on a hip-joint chair, clearly defined under the axonometric perspective system, but it`s hard to reinterpret as such, if the reader does not known well this kind of seat and the axonometric system. (Figure 5)

Figure 5. Left: Tlatelolco Codex plate 1, Detail, representing the chief sitting on a hip-joint chair, ca. 1562; the original document is in the National Library of Anthropology and History, sig. 35-39; Retrieved from INAH Media Library, https://mediateca.inah.gob.mx/repositorio/islandora/object/fotografia: 281368; Right: Drawing of a hip joint chair. Author: Arturo Adame Ruiz

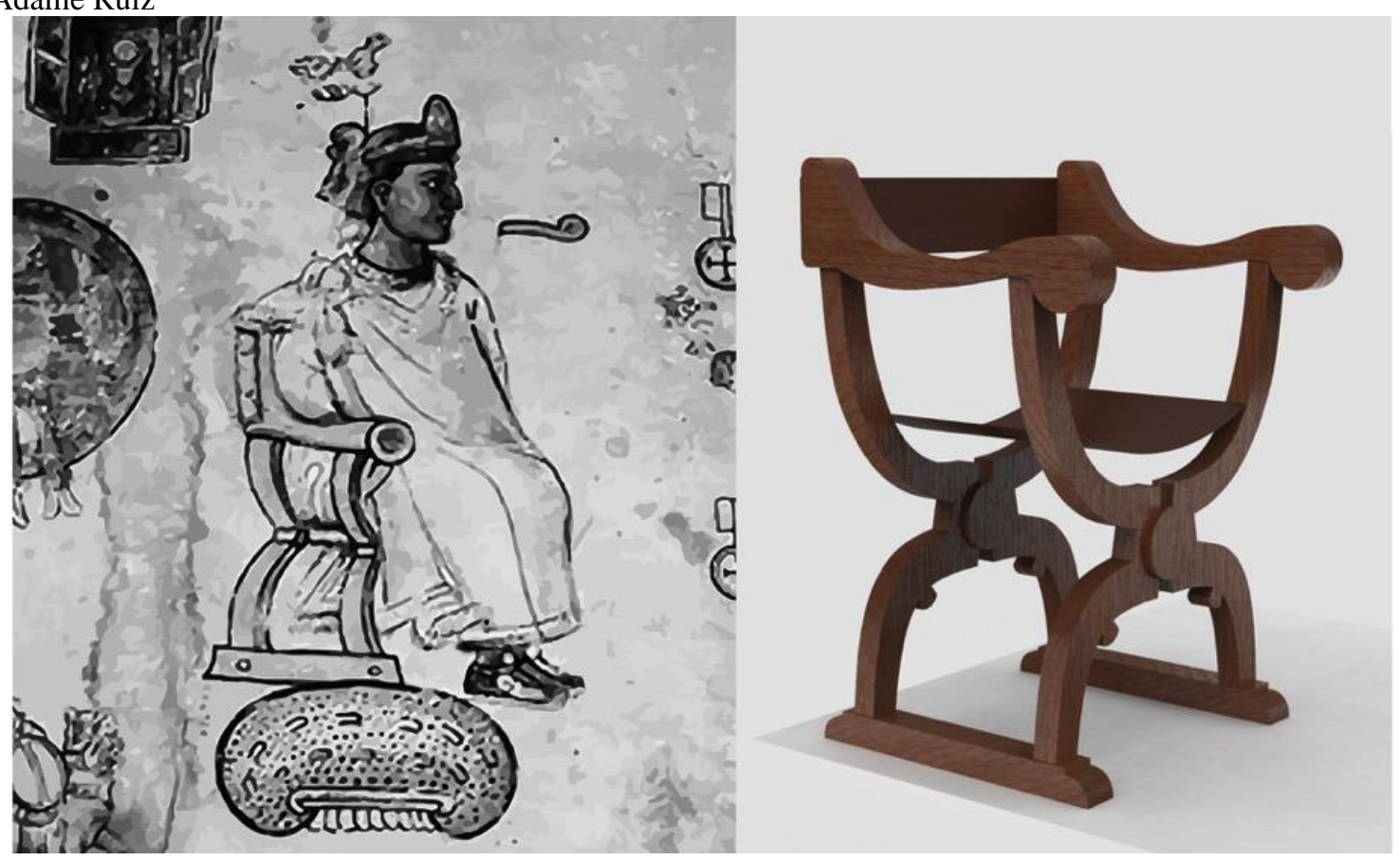


Unlike, for example, in the San Juan Teotihuacán Codex, dated from the middle of the sixteenth century, the friars appear sitting in another kind of seats, very similar to the hip-joint chair, but the " $\mathrm{X}$ " shape uprights are on the sides; In the Yanhuitlán Codex developed in 1544, the entruster and his brother appear sitting on similar chairs, although the drawing was developed in more detail, it denotes a greater European influence on the stroke. Also, in the Huejotzingo Codex dated in 1568, in two of it sheets appear, the mayor appointed by the king seated on the same kind of seat. (Figure 6)

Figure 6. Colonial Codices: San Juan Teotihuacán Codex Detail, $16^{\text {th }}$ Century, original is kept at the Dr. Eusebio Dávalos Hurtado Anthropology and History National Library, (BNAH); Yanhuitlán Codex Plate, Ca. 1544, reprography. I.O. "CXLVIII-99, National Photo Library, recovered from: INAH Media Library; Huejotzingo Codex plate 1AA Detail, 16 ${ }^{\text {th }}$ Century, original is kept at the Dr. Eusebio Dávalos Hurtado Anthropology and History National Library (BNAH). Tlaxcala Codex Detail, $16^{\text {th }}$ Century, Copy made by José Manuel Yllañez in 1773, kept at the BNAH, recovered from https://www.codices.inah.gob.mx/movil/conten.php?id=50 . Drawings: J A I.

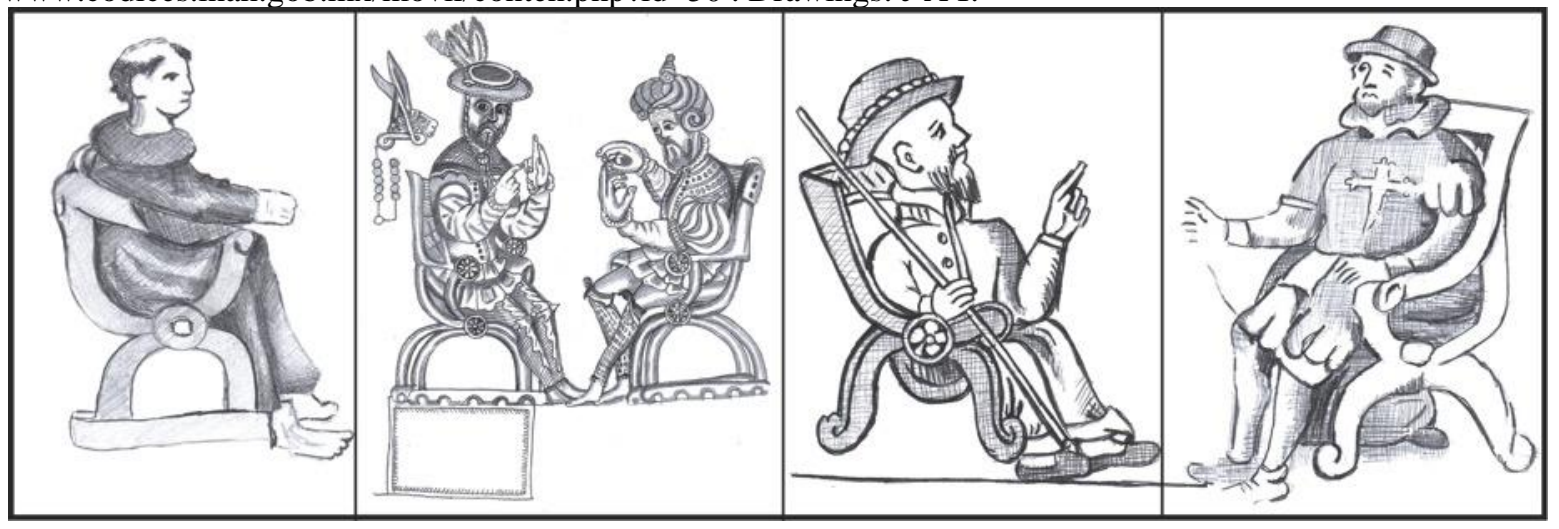

In the document known as the Tlaxcala Codex, elaborated between the $1535-1550^{4}$ years, commissioned by the civil authorities in order to demonstrate to the Spanish crown the alliances that Tlaxcala people did with Captain Hernán Cortés to submit the Mexica Empire; in this document there are represented many elements, from both pre-Hispanic and European origin; In the lower part there are 87 small scenes that address various topics such as the arrival of the Spaniards, the alliances they made with the Tlaxcalan, the conquest in its different phases, the Cholula killing and the defeat of Cuauhtémoc; At the top, the political structure of Tlaxcala is presented, with 13 Spanish characters on seats that present the $\mathrm{X}$-shape in its side.

Manuel Toussaint, referring to this canvas, affirms that this seat is "... the Florentine Folding chair, which forms a curvilinear angle towards the bottom, which is repeated up to make the seat..." but it is just represented from the front and the armrests were placed as if it was in the side, and he attributes this to the tlacuilo clumsiness. (Toussaint, 1990)

If its consider that the pictographic language of the tlacuilo, which took the objects most

\footnotetext{
${ }^{4}$ It is worth mentioning that 3 originals were produced, one was sent to King Felipe II, another remained in Tlaxcala and another was sent to Mexico City, although its whereabouts are currently unknown, the copy kept in the Library of the National Institute of Anthropology and History is a copy made in 1773 by José Manuel Yllañez
} 
predominant characteristics to represent them in the scenes that he painted, we can deduce that it is the hip-joint chair by the stringers position, and because it was the mostly used Spanish seat in 16th century. In these documents, the seat that is represented in the scenes, have the particularity of the X shape uprights are located on the sides, but according to the present interpretation of the technical drawing and the axonometric perspective, it is in the side views of the seat; The rosette that marks the intersection of both stringers is also represented, as well as the base that unites the previous and subsequent supports, that would prevent folding or the "scissors". (Figure 7)

Figure 7. Tlaxcala Codex Detail, “C” frame, S. XVI, 1773 José Manuel Yllañez, “Dr. Eusebio Dávalos Hurtado” Anthropology and History National Library BNAH, recovered from https://www.codices.inah.gob.mx/movil/contente.php? id = 51 Drawing from the INAH Media Library original, prepared by J A I; Right, Butaque digital drawing, based on the copy kept in the El Palacio museum in Campeche, prepared by A. A. R.

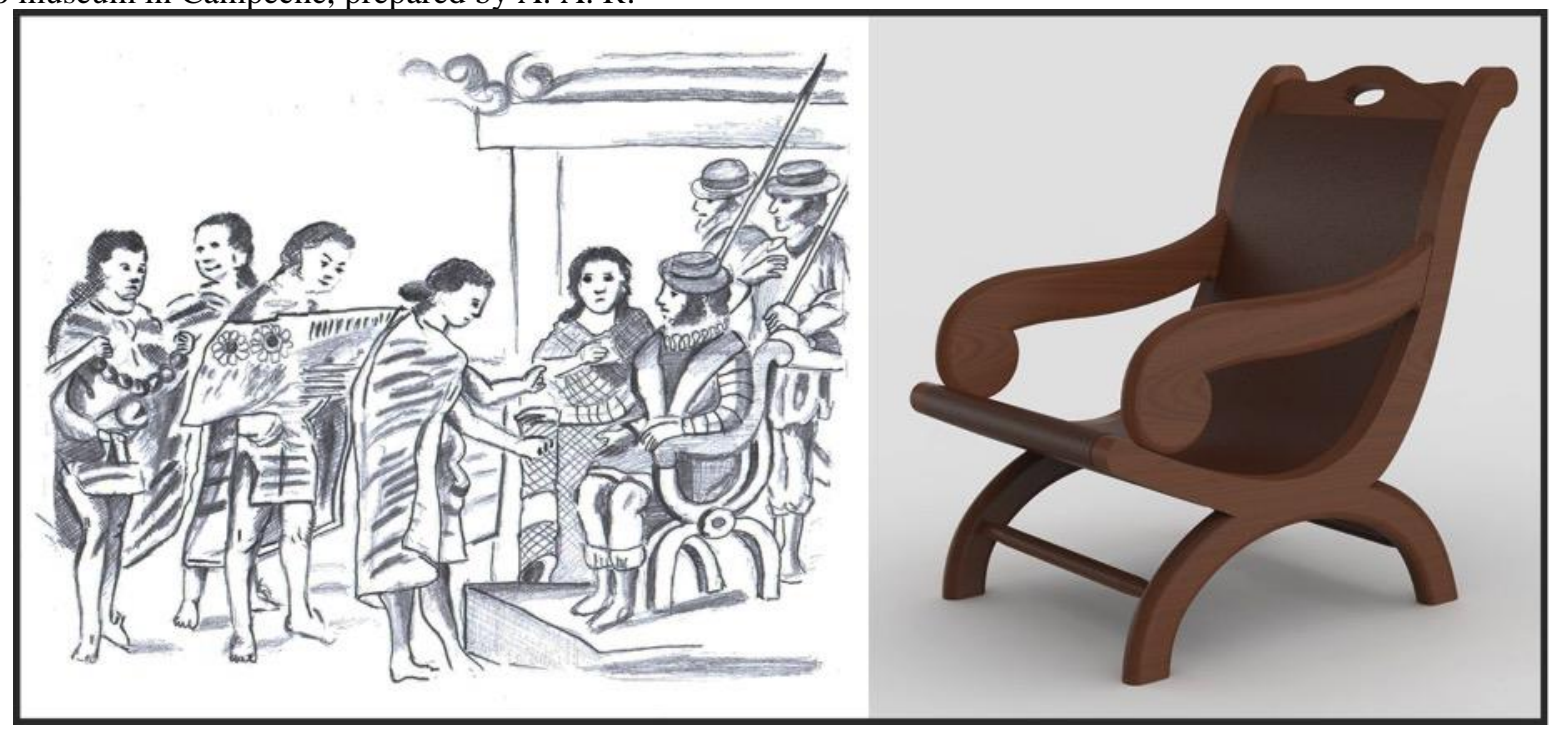

If it observe the butaques oldest specimens, there is a notorious reference to the chairs in the colonial codices profile representations, but even more notorious in those butaque specimens elaborated by the indigenous groups in the Gulf of Mexico and the Yucatan peninsula region along the nineteenth and twentieth centuries, in which this resemblance is more evident.

Then it is possible that in subsequent generations, indigenous carpenters and artisans, who had already assimilated the graphic Renaissance system language and its interpretation, and if the only references for the development of furniture were colonial codices, the result of that re-reading under the European canons, the result of this reinterpretation was the butaque. When comparing pictograms, especially the Tlaxcala Codex pictograms, with the rustic ones, which are preserved at the Cultural Center "El Palacio", in the city of Campeche, and at the Mayan World Great Museum of Mérida, the similarity between both seats is notable, as if the pictographic representation on the sixteenth century would have served as a reference for the butaque construction, with small differences in terms of elements that will 
grant greater stability.

Based on the butaque popularity and at the same time, on technological and technical development, the artist was able to reinterpret it according to his own abilities and some adaptations according to the target market for which they were elaborate, then variables with wavy armrests appear, diversity of carved or embedded crests (inlaid wood and / or marquetry), turned or simple cross bars, simple leather or painted or chiseled leather the finest ones, knitted vegetal fiber seat and back, or the modest ones, that were made with wood boards.

\section{CONCLUSIONS}

Both authors, Toussaint (1948) and Carrillo (1957) noted the difference between the hip-joint chair and the seat represented in the 16th century codices: the position of the half arch formed by the lower supports in its side view, not in its front view as corresponds to the hip-joint chair. Also, both authors agree that it is a different type of seat and it was not documented in chronicles or inventories, except in these codices, but not compared to the butaque probably because it is a seat, which was then better known outside Mexico City.

If, as previously stated, the butaque arose in the seventeenth century from the rereading of colonial codices, which has been created in a previous century, and its production and use was extended to the predominantly indigenous and rural mestizo population who adapted the shape with available materials from each region, through time, the butaque earned the vernacular furniture attribute.

In the twentieth century, architects and designers, following the Vasconcelos aesthetic philosophy, for the Mexican cultural identity dissemination through nationalist post-revolutionary art in all its expressions, and their work was nationally and internationally recognized, it was then that the butaque claimed its importance, since those designer and architects took a traditional and rural piece of furniture, that by reproducing and reinterpreting it in many ways, with different materials, techniques and better quality finishes, the butaque left its provincial and popular character to insert them self in the intellectual circles and "high society" residences; with this new category, it was set on the collective imaginary transcending throughout the 20th century, which gave it the modern Mexican furniture identity value.

Dr. Rivas bases the origin of the butaque on the reinterpretation of the tainian people ceremonial duho seat, and its diffusion from Venezuela to New Spain; The hypothesis here discussed presents the possibility of the origin in the rereading of the Mexican colonial codices, which were originally elaborated in the pictographic language resulting from the pre-Hispanic and Renaissance combination of representing reality, and the reinterpretation of these codices under a different drawing system and norms. However, no matter how different the positions may be, it is agreed that the butaque is a product, like the Latin 
American culture, of the combination of traditions and knowledge from both, American and European cultures.

Figure 8. Author butaques: top left to right: William Spratling, Ca. 1935, retrieved from: https://donshoemaker.com/the-revivalof-the-butaque-chair-in-mexican-20th-century-furniture- design-part-3 / \# jp-carousel-5817, drawing: JAGC; Sabino wood and jute fabric, Clara Porset, ca.1950, DI Jorge Enrique Yañez collection, photography: Guillermo Soto, Taken from: The Clara Porset Design, Co Ed. UNAM, Franz Mayer CIDI, p. 124, drawing by: JRRT; Josef Albers, 1940, Private Collection, photograph recovered from: https://www.sothebys.com/en/auctions/ecatalogue/2017/important-design-n09650/lot.41.html, drawing from: MATA; bottom: Luis Barragán, 1947, Modern Art Museum collection, México City, photograph: MJHP, drawing by: AJRT; Manuel Parra, ca. 1950, private collection, photograph recovered from ADN Galería.com, 09-24-2019, drawing by: MATA; Alejandro Rangel Hidalgo, 1965-1970, Alejandro Rangel Hidalgo University Museum, Nogueras, Col., photograph: MHP, drawing by: AJRT.
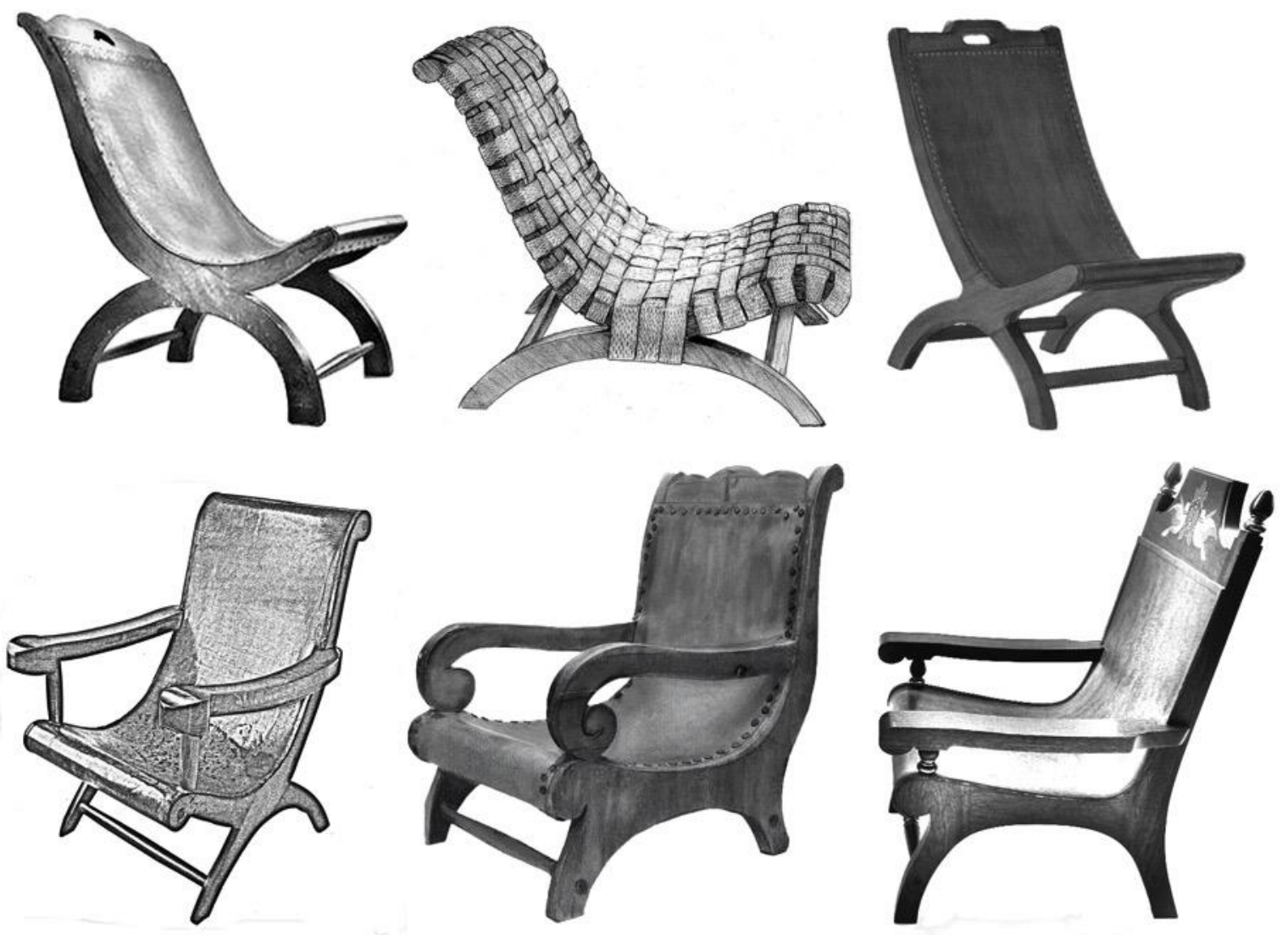


\section{BIBLIOGRAPHY}

Calderón Pichardo, M. C. (2018). José Vasconcelos. diferencia y continuidad del proyecto de nación. Revista Digital Universitaria , 19 (5), 1-12.

Castello de Yturbide, T. (1969). Regional Furniture. El mueble mexicano (118), 76-83.

Carrillo y Gariel, A. (1957). Evolución del mueble en México. México: INAH.

Díaz del Castillo, B. (1795). Historia verdadera de la Conquista de la Nueva España (Vol. 1). Madrid, España: Benito Cano.

Escalante Gonzalbo, P. (2010). Los códices mesoamericanos antes y después de la conquista española. Historia de un lenguaje pictográfico. México: Fondo de Cultura Económica.

Galarza, J. (1996). Iconio. Recuperado el 29 de agosto de 2019, de Iconio: http://www.iconio.com/ABCD/F/INDEX.PDF

Garabana, A. F. (1969). El mueble del siglo XVI y su origen español. In T. Castelló Yturbe, El mueble mexicano (pp. 8-14). México: Artes de México.

Gontar, C. T. (2003). The Campeche Chair in The Metropolitan Museum of Art. Metropolitan Museum Journal , 181-212.

Murillo, G. (1985). Las artes populares en México. México: Instituto Nacional Indigenista.

Mallet, A. E. (2017). Silla Mexicana. México: Arquine/Secretaría de Cultura.

Philadelphia Museum of Art. (24 de Mayo de 2018). Philadelphia Museum of Art. Obtenido de On line Collection: https://www.philamuseum.org/collections/permanent/313148 html?mulR=2113741750|1

Oettinger, M. J. (2009). Tesoros del Arte Popular Mexicano, colección Nelson A. Rockefeller. México: Artes de México.

Rivas P., J. F. (2007). Observaciones sobre el origen, desarrollo y manufactura del mobiliario en América Latina. En J. J. Rishel, \& S. Stratton-Pruit, Revelaciones, Las artes en América Latina 1492 - 1820 (págs. 484 - 515). México: Fondo de Cultura Económica.

Rivas Pérez, J. F. (2017). Butacas y butaques: sillas nuevas para el Nuevo Mundo. En A. E. Mallet, Silla Mexcana (págs. 29-34). México: Arquine.

Toussaint, M. (1990). Arte colonial en México. México: UNAM/IIE.

Trillo, M. (17 de 06 de 2018). ABC Internacional. Recuperado el 7 de 08 de 2019, de ABC: https://www.abc.es/internacional/abci-cuando-espana-dominaba-gigantescas-texas-y-luisiana-punado-hombres201806141821_noticia.html?ref=https:\%2F\%2Fwww.google.com

Valle, P. (2008). Códice de Tlatelolco. Arqueología Mexicana (89), 66-70.

Drawings elaborated by:

JAGC: José Alberto Guzmán Castañeda

JRRT: Juan Ramón Rauda Torres

MATA: María Azucena Tejeda Ayala

AJRT: Anderson Jovanni Ramírez de la Torre

JAIJ: José Antonio Ibarra Jiménez

AAR: Arturo Adame Ruiz

AMTR: Amelia Mariel Torres Rodríguez 